\title{
Analisis Buku Tematik Kelas 1 SD/MI Muatan Matematika Tema 1 Diriku
}

\author{
Jannah Ulfah ${ }^{1^{*}}$, Rizka Febriyani Awliyah ${ }^{2}$, Auliya Fia ${ }^{3}$, Nelsa Putri Ayu ${ }^{4}$, \\ Halimatun $\mathrm{Nisa}^{5}$ \\ 1,2,3,4,5Magister Pendidikan Guru Madrasah Ibtidaiyah, FITK, UIN Sunan Kalijaga \\ Yogyakarta, Yogyakarta, Indonesia; "janahulfa9@gmail.com
}

\begin{abstract}
Abstrak. Pendidikan merupakan usaha sadar dan terencana untuk mewujudkan suasana belajar dan proses pembelajaran agar anak didik secara aktif mengembangkan potensi dirinya. Saat ini dalam dunia pendidikan kurikulum yang diterapkan adalah kurikulum 2013. Buku yang digunakan dalam menerapkan kurikulum 2013 adalah buku tematik. Buku tematik merupakan buku yang disediakan oleh pemerintah yang didalamnya memuat beberapa tema yang digunakan untuk mengaitkan beberapa konsep mata pelajaran, sehingga peserta didik akan lebih mudah memahami sebuah konsep. Salah satu materi yang ada dalam buku tematk kurikulum 2013 di kelas 1 sekolah dasar adalah materi matematika. Penelitian ini bertujuan untuk menganalisis materi pembelajaran matematika pada tema 1 Diriku yang ada dalam buku Tematik Kurikulum 2013 Sekolah Dasar kelas 1. Jenis penelitian yang dilakukan adalah studi kepustakaan dengan pendekatan kualitatif. Desain penelitian ini merupakan analisis isi (content analisis). Analisis isi ini digunakan untuk menganalisis materi matematika yang ada pada buku Tematik Kurikulum 2013 kelas 1 Sekolah Dasar. Teknik yang digunakan dalam penelitian ini adalah dokumentasi. Hasil penelitian menunjukkan bahwa pada materi matematika yang diajarkan di kelas 1 sekolah dasar terutama mengenai bilangan masih terdapat kekurangan yang perlu diperbaiki.
\end{abstract}

Kata Kunci: Analisis, Buku Tematik, Materi Matematika

\begin{abstract}
Education is a conscious and planned effort to create an atmosphere of learning and learning process so that students actively develop their potential. Currently in the world of education, the curriculum applied is the 2013 curriculum. The books used in implementing the 2013 curriculum are thematic. Thematic books are books provided by the government which contains several themes used to link several concepts of subjects, so students will more easily understand a concept. One of the materials in the 2013 curriculum book in grade 1 elementary school is mathematics material. This study aims to analyze the mathematics learning material on the theme 1 Myself in the Thematic Curriculum 2013 Primary School Class 1 book. The type of research conducted is a literature study with a qualitative approach. The design of this research is content analysis. This content analysis is used to analyze the mathematical material in the 2013 Class 1 Primary School Curriculum Thematic book. The technique used in this research is documentation. The results showed that the mathematics material taught in grade 1 elementary schools, especially regarding numbers, there are still deficiencies that need to be corrected.
\end{abstract}

Keywords: Analysis, Thematic Book, Mathematical Material

\section{Pendahuluan}

Pendidikan merupakan suatu usaha bagi pendidik untuk dapat mengembangkan potensi yang dimiliki oleh peserta didik. Mengembangkan potensi yang ada dalam diri peserta didik sangatlah penting. Pada jenjang sekolah, pendidikan dasar merupakan jenjang pendidikan pertama yang 
merupakan pondasi awal dari pendidikan. Pendidikan dasar bertujuan untuk mengembangkan potensi yang ada dalam diri peserta didik, seperti: kemampuan intelektual, mental, proses pengembangan sebagai individu yang mandiri, proses perkembangan sebagai makhluk social, belajar hidup menyesuaikan diri dengan berbagai perubahan, dan meningkatkan kreativitas (Prastowo, 2013). Saat ini dalam dunia pendidikan kurikulum yang diterapkan adalah kurikuum 2013.

Penerapan kurikulum 2013 ini diyakini mampu untuk dapat mengetasai permasalahan yang belum terselesaikan pada kurikulum sebelumnya (KTSP) sehingga kualitas program pendidikan yang ada di Indonesia akan lebih baik. Kurikulum sebelumnya guru dan peserta didik menggunakan buku yang sama, sedangkan pada kurikulum 2013 pemerintah menyediakan buku guru dan buku siswa sebagai sumber belajar di sekolah. Buku yang disediakan oleh pemerintah adalah buku tematik. Pembelajaran tematik yang diajarkan di sekolah adalah pembelajaran yang berdasarkan sebuah tema yang kemudian dikaitkan dengan beberapa konsep mata pelajaran, sehingga memudahkan peserta didik memahami apa yang dijelaskan oleh guru. Dengan begitu peserta didik akan mendapatkan pembelajaran yang bermakna (Wahyuni, Setyosari, \& Kuswandi, 2016). Materi yang ada pada sebuah buku teks pelajaran menempat posisi yang sangat penting dari keseluruhan kurikulum yang harus dipersiapkan agar dalam pelaksanaan pembelajaran sasaran yang diinginkan dapat tercapai.

Sasaran tersebut harus sesuai dengan tuntutan yang ada pada kurikulum, artinya materi yang ditentukan untuk kegiatan pembelajaran hendaknya materi yang benar-benar menunjang tercapainya standar kompetensi lulusan peserta didik pada tiap jenjang pendidikan. Salah satu materi yang ada dalam buku tematk kurikulum 2013 di kelas 1 sekolah dasar adalah materi matematika. Matematika merupakan mata pelajaran yang diajarkan mulai dari jenjang kanak-kanak, sekolah dasar sampai perguruan tinggi. Belajar matematika merupakan hal dasar yang wajib dipelajari. Matematikan adalah salah satu disiplin ilmu yang sangat diperlukan dalam kegiatan sehari-hari (Kurniawan, Tambunan, \& Sardi, 2015). Pengaplikasian matematika sering digunakan dalam melaksanakan aktivitas dalam segala bidang, baik bidang pedidikan, perdagangan, sosial, serta mampu mengarahkan manusia untuk berfikir secara logis dan memberikan solusi yang tepat.

Bilangan merupakan hal yang tidak terlepas dalam mempelajari matematika. Salah satu bagian dari klasifikasi bilangan adalah operasi-operasi yang berlaku pada bilangan yaitu penjumlahan, pengurangan, perkalian dan 
pembagian. Operasi-operasi pada bilangan ini sudah diajarkan di jenjang sekolah dasar mulai kelas 1. Belajar matematika merupakan satu proses yang terkait dengan ide-ide, gagasan, aturan atau hubungan yang diatur secara logis sehingga dalam belajar matematika harus mencapai pemahaman (Hasanah, Hafsi, \& Zayyadi, 2019). Tujuan dari mempelajari matematika adalah mampu memahami konsep matematika. Peserta didik diharapkan dapat mengerti konsep matematika yang diajarka oleh guru. Matematika yang diajarkan di sekolah pada jenjang pendidikan dasar yaitu bertujuan agar peserta didik dapat memecahkan permasalahan yang berkaitan dengan matetamatika dalam kehidupan sehari-hari seperti membeli buku, pensil, penghapus, dan lain sebagainya.

Berdasarkan penjelasan di atas dapat kita pahami bahwa mempelajari matematika ini sangat penting untuk dapat melakukan operasi hitung pada bilangan dengan baik dan dapat diterapkan dalam kehidupan sehari-hari. Hal ini sejalan dengan pendapat Rukiah (2018) yang mengungkapkan bahwa fungsi matematika adalah untuk mengembangkan kemampuan menghitung, menurunkan, mengukur, dan menggunakan rumus matematika sedrhana yang diperlukan dalam kegiatan sehari-hari. Objek langsung yang diperoleh dalam belajar matematika adalah fakta, keterampilan, konsep dan aturan. Operasi hitung merupakan kemampuan matematika yang sangat penting dipelajari dan sangat diperlukan untuk menyelasaikan persoalan dalam kehidupan sehari-hari yang bersifat matematis.

Pada kurikulum 2013, pemerintah menyediakan buku tematik kurikulum 2013 sebagai pegangan dalam proses pembelajaran. Dalam buku tersebut terdapat materi matematika yang akan diajarkan pada saat proses pembelajaran. Meninjau materi pembelajaran matematika di kelas 1 sekolah dasar ini, penulis akan menganalisa 1. Tema; 2. Kesesuaian materi dengan KD; 3. Kesesuaian materi antara buku guru dengan buku siswa. Materi pembelajaran merupakan hal yang pokok sehigga perlu diperhatikan. Oleh karena itu penulis melakukaan analisis materi matematika yang ada di buku tematik kurikulum 2013 di kelas 1 sekolah dasar.

\section{Metode}

Jenis penelitian yang digunakan dalam penelitian ini adalah studi kepustakaan yaitu penelitan yang didasarkan atas penelusuran literatureliteratur yang berkaitan dengan masalah-masalah yang akan dibahas (Sugiono, 2013). Dalam penelitian pustaka ini data diperoleh melalui penggalian dan penelusuran terhadap buku-buku, artikel, jurnal, dan catatan lainnya yang mendukung berkaitan dengan pemecahan masalah dalam 
penelitian ini. Sumber utama penelitian ini adalah buku tematik kurikulum 2013 kelas 1 sekolah dasar. Pendekatan yang digunakan dalam penilitian ini adalah pendekatan kualitatif, karena pada penelitian ini lebih menekankan pada pengumpulan data yang bersifat kualitataif.

Desain penelitian ini merupakan analisis isi (content analisis). Analisis isi digunakan untuk mengetahui materi matematika yang ada pada buku Tematik Kurikulum 2013 kelas 1 Sekolah Dasar. Teknik yang digunakan dalam penelitian ini adalah dokumentasi. Dokumentasi merupakan teknik yang dilakukan peneliti untuk mengumpulkan data (Putra, 2012). Dokumentasi digunakan untuk mendapatkan data-data yang berhubungan dengan materi matematika.

\section{Hasil dan Pembahasan}

\section{Tema dan KD Muatan Matematika Pada Buku Tematik Kelas 1 SD/MI}

Berdasarkan hasil analisis muatan matematika pada Buku Tematik Kurikulum 2013 Kelas 1 SD/MI terbitan Kemendikbud dapat disajikan pada bagan berikut ini:

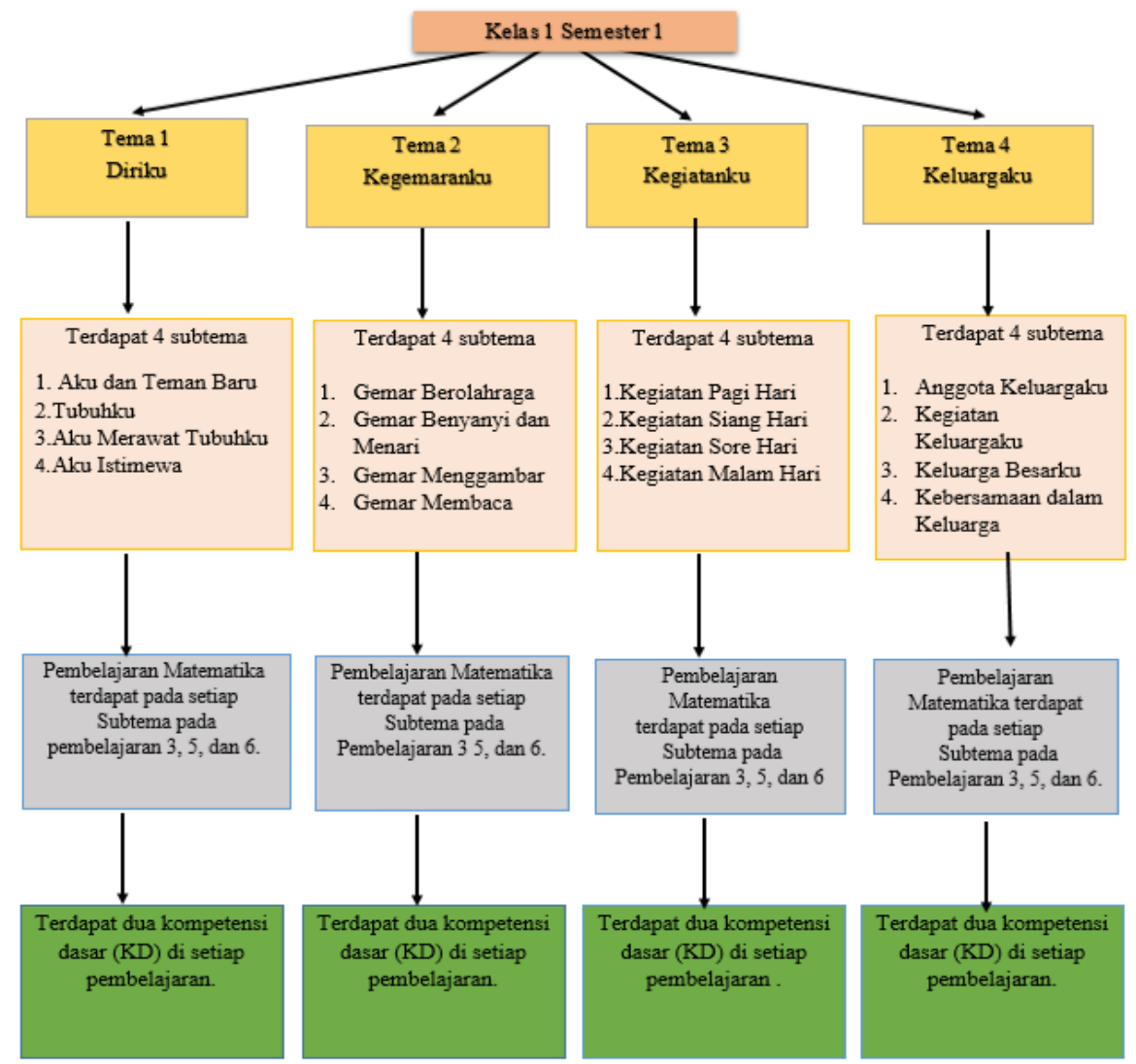

Gambar 1. Peta Konsep Pembelajaran Matematika Buku Tematik Kelas 1 Sekolah Dasar (Semester 1) 
Gambar 1 menunjukan pemetaan pembelajaran matematika di semester 1 pada Buku Tematik Kurikulum 2013 Kelas 1 SD/MI terbitan Kemendikbud. Pada semester 1 terdapat 4 tema, tema tersebut yaitu memuat; Tema 1 Diriku, Tema 2 Kegemaranku, Tema 3 Kegitanku, Tema 4 Keluargaku. Pada tema 1 Diriku, terdapat 4 subtema yaitu; 1) Aku dan Teman Baru; 2) Tubuhku; 3) Aku Merawat Tubuhku; 4) Aku Istimewa. Setiap subtema pada tema 1 ini terdiri dari 6 pembelajaran, akan tetapi pembelajaran matematika hanya ada 3 pembelajaran yaitu pada pembelajaran 3,5, dan 6. Pada setiap pembelajaran matematika terdapat $2 \mathrm{KD}$.

Pada tema 2 Kegemaranku, terdapat 4 subtema yaitu; 1) Gemar Berolahraga; 2) Gemar Bernyayi Dan Menari; 3) Gemar Menggambar; 4) Gemar Membaca. Setiap subtema pada tema 2 ini terdiri dari 6 pembelajaran, akan tetapi pembelajaran matematika hanya ada 3 pembelajaran yaitu pada pembelajaran 3, 5, dan 6. Pada setiap pembelajaran matematika terdapat 2 KD.

Pada tema 3 Kegiatanku, terdapat 4 subtema yaitu; 1) Kegiatan pagi hari; 2) Kegiatan Siang Hari; 3) Kegiatan Sore Hari; 4) Kegiatan Malam Hari. Setiap subtema pada tema 3 ini terdiri dari 6 pembelajaran, akan tetapi pembelajaran matematika hanya ada 3 pembelajaran yaitu pada pembelajaran 3, 5, dan 6 . Pada setiap pembelajaran matematika terdapat 2 KD.

Pada tema 4 Keluargaku, terdapat 4 subtema yaitu; 1) Anggota Keluargaku; 2) Kegiatan Keluargaku; 3) Keluarga Besarku; 4) Kebersamaan dalam Keluarga. Setiap subtema pada tema 4 ini terdiri dari 6 pembelajaran, akan tetapi pembelajaran matematika hanya ada 3 pembelajaran yaitu pada pembelajaran 3, 5, dan 6. Pada setiap pembelajaran matematika terdapat 2 KD. 


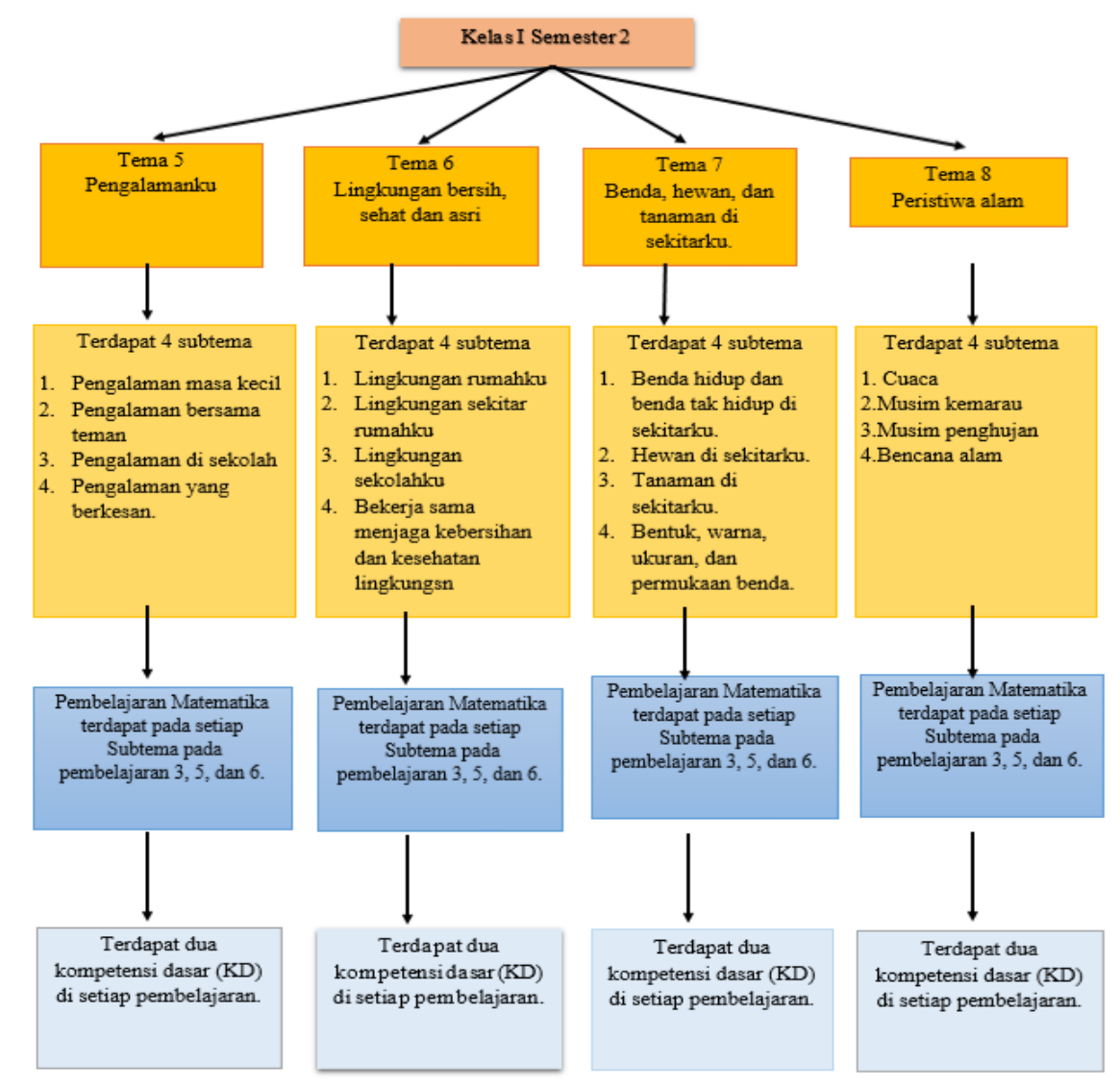

Gambar 2. Peta Konsep Pembelajaran Matematika Buku Tematik Kelas 1 Sekolah Dasar (Semester 2)

Gambar 2. adalah pemetaan pembelajaran matematika di semester 2 pada Buku Tematik Kurikulum 2013 Kelas 1 SD/MI terbitan Kemendikbud. Pada semester 2 ini melanjutkan tema dari semesterter 1. Terdapat 4 tema di semester 2 yaitu; Tema 5 Pengalamanku; Tema 6 Lingkungan Bersih, Sehat dan Asri; Tema 7 Benda, Hewan dan Tanaman di Sekitarku; Tema 8 Peristiwa Alam. Pada tema 5 Pengalamanku, terdapat 4 subtema yaitu; 1) pengalaman masa kecil; 2) pengalaman bersama teman; 3) pengalaman di sekolah; 4) pengalaman yang berkesan. Setiap subtema pada tema 5 ini terdiri dari 6 pembelajaran, akan tetapi pembelajaran matematika hanya ada 3 pembelajaran yaitu pembelajaran 3,5, dan 6. Pada setiap pembelajaran matematika terdapat $2 \mathrm{KD}$.

Pada tema 6 Lingkungan Bersih, Sehat, dan Asri, terdapat 4 subtema yaitu; 1) lingkungan rumahku; 2) lingkungan sekitar rumahku; 3) lingkungan sekolahku; 4) bekerja sama menjaga kebersihan dan kesehatan lingkungan. Setiap subtema pada tema 6 ini terdiri dari 6 pembelajaran, akan tetapi pembelajaran matematika hanya ada 3 pembelajaran yaitu pembelajaran 3, 5, dan 6. Pada setiap pembelajaran matematika terdapat $2 \mathrm{KD}$. 
Pada tema 7 Benda, Hewan, dan Tanaman di Sekitarku, terdapat 4 subtema yaitu; 1) benda hidup dan benda tak hidup di sekitarku; 2) hewan di sekitarku; 3)tanaman di sekitarku; 4) bentuk, warna, ukuran, dan permukaan benda. Setiap subtema pada tema 7 ini terdiri dari 6 pembelajaran, akan tetapi pembelajaran matematika hanya ada 3 pembelajaran yaitu pembelajaran 3,5 , dan 6. Pada setiap pembelajaran matematika terdapat 2 KD.

Pada tema 8 Peristiwa Alam, terdapat 4 subtema yaitu; 1) cuaca; 2)musim kemarau; 3)musim penghujan; 4) bencana alam. Setiap subtema pada tema 7 ini terdiri dari 6 pembelajaran, akan tetapi pembelajaran matematika hanya ada 3 pembelajaran yaitu pembelajaran 3,5 , dan 6 . Pada setiap pembelajaran matematika terdapat $2 \mathrm{KD}$.

\section{Kesesuaian KD dengan Materi dan tujuan pembelajaran matematika}

Berdasarkan analisis antara materi matematika dengan KD terdapat temuan penulis yang menunjukkan kurang sesuainya materi matematika dengan KD. Pada tema 1 Diriku, subtema 1 pembelajaran 3 pada muatan matematika terdapat 2 KD, yaitu KD (3.1) dan KD (4.1) dalam KD tersebut menjelaskan dan menyajikan bilangan cacah sampai dengan 99. Sedangkan dalam materi dan tujuan pembelajaran siswa mengenal bilangan 1 sampai dengan 10 . Untuk lebih jelasnya dapat di lihat pada gambar berikut ini:

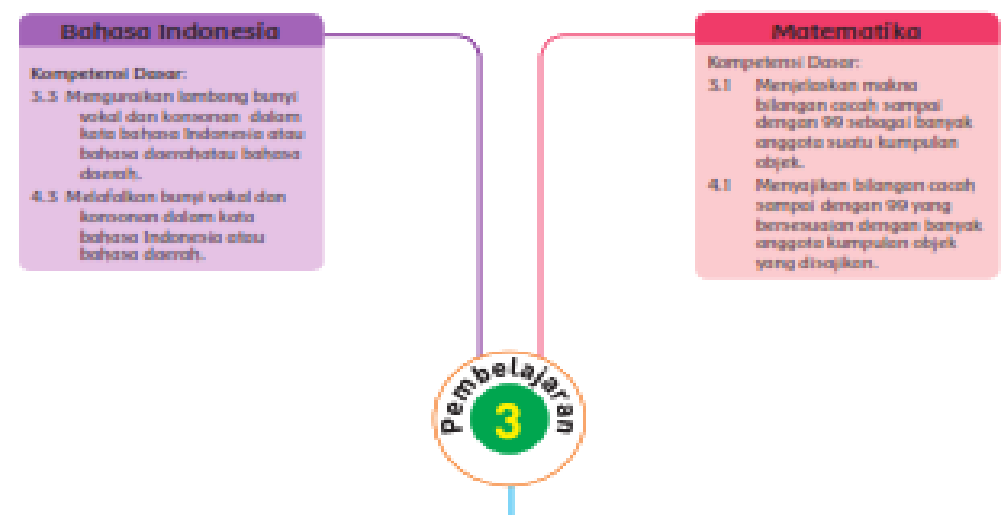

Gambar 3. KD Subtema 1 Pembelajaran 3 


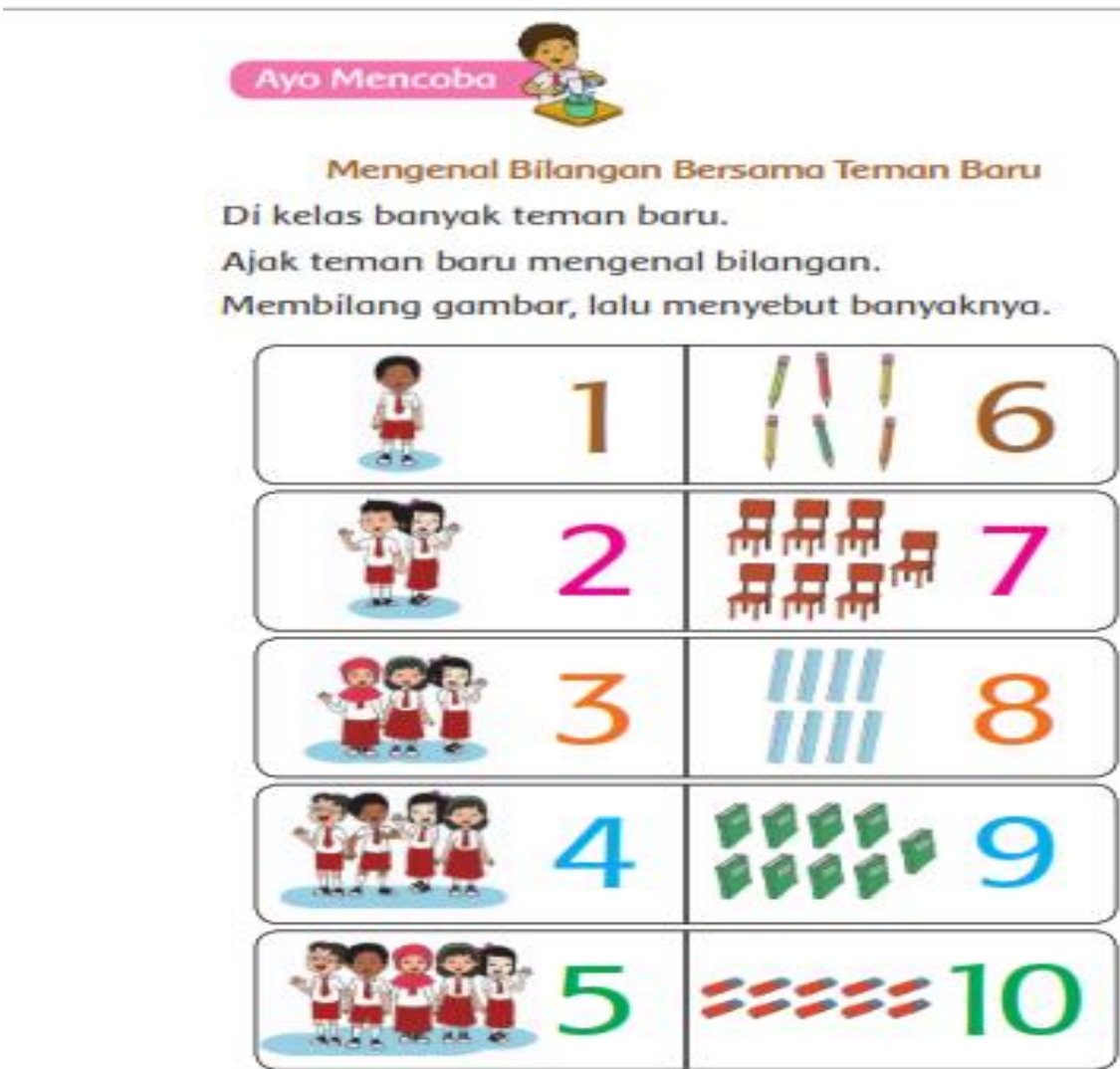

Suberna 1: aku dan Terman Bon (15

Gambar 4. Materi Matematika Subtema 1 Pembelajaran 3

Dari gambar 3 dan gambar 4 di atas dapat kita pahami bahwa kurangnya kesesuaian antara KD dengan materi yang ada di buku siswa. Di dalam KD subtema 1 pembelajaran 3 terdapat 2 KD, yaitu KD 3.1 dan 4.1. KD tersebut memuat mengenai siswa mampu menjelaskan makna bilangan cacah sampai dengan 99 dan mampu menyajikan bilangan cacah sampai dengan 99. Hal ini tidak sesuai dengan materi yang ada di buku siswa. Dalam buku siswa dapat kita lihat pada gambar 3 bahwa siswa dikenalkan bilangan 1-10. Akan tetapi dalam buku siswa tersebut contoh gambar yang digunakan dalam mengenal bilangan sudah baik, gambar yang digunakan adalah benda-benda sekitar yang ada di kelas sehingga mudah dipahami oleh siswa.

Berdasarkan analisis yang dilakukan bahwa materi matematika dan KD yang ada di buku siswa dan buku guru sebagian besar sudah sesuai. Contoh-contoh yang ada di buku dalam mengenal bilangan mudah dipahami oleh siswa. Materi yang ada di buku siswa seperti mengenal bilangan, melakukan penjumlahan dan pengurangan mudah dipahami oleh peserta didik. Contoh dalam penjumlahan pada tema 1subtema 4 pembelajaran 5 sebagai berikut; 


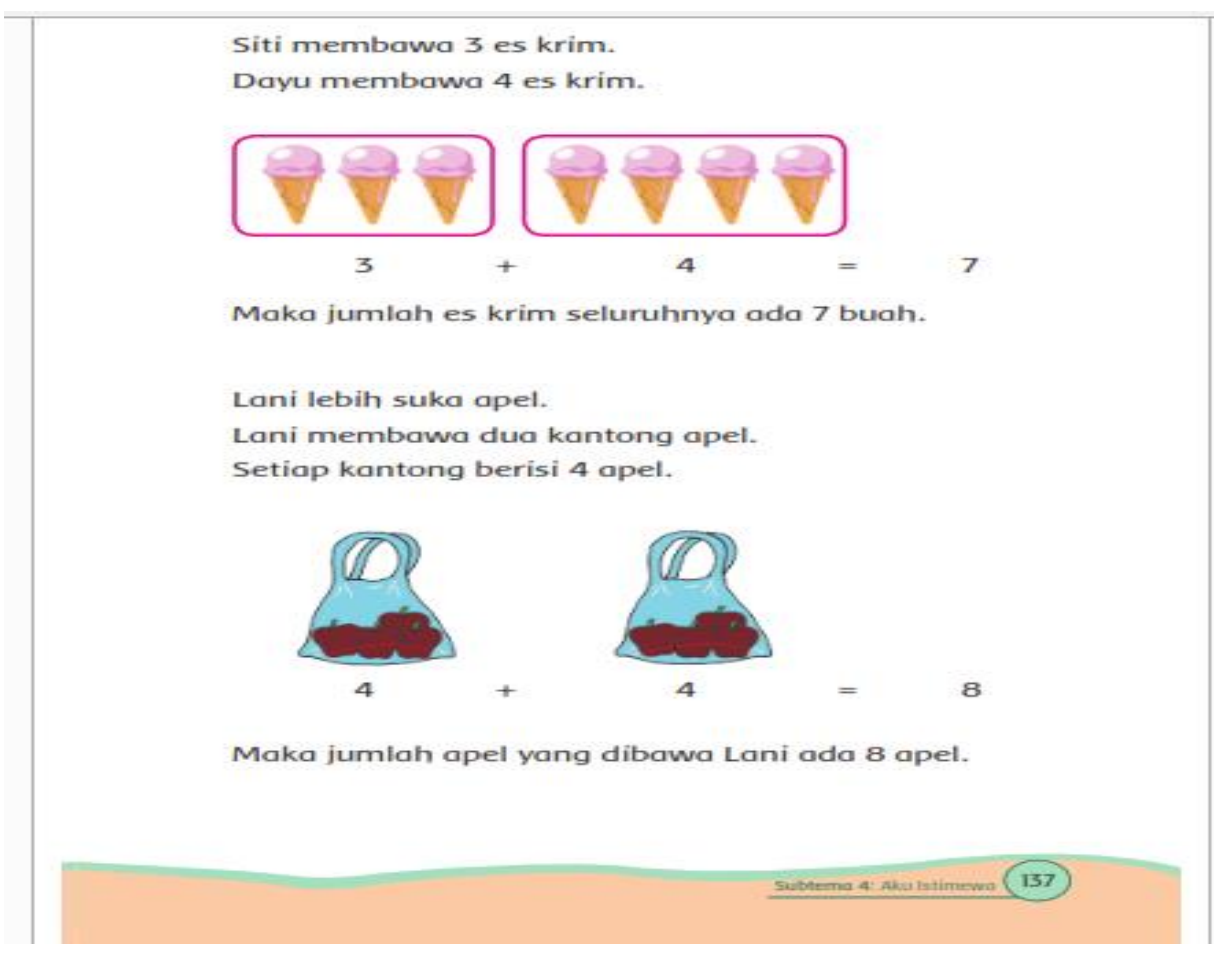

Gambar 5. Contoh penjumlahan pada subtema 4 pembelajaran 5

Pada gambar 4 merupakan contoh penjumlahan yang ada di subtema 4 pembelajaran 5. Contoh gambar yang ada di buku siswa ini sederhana dan gambar yang digunakan adalah benda-benda yang ada dalam kehidupan sehari-hari. Sehingga peserta didik mudah memahami tentang materi yang diajarkan. Dengan memberikan contoh seperti gambar di atas diharapkan peserta didik dapat memecahkan masalah yang berkaitan dengan penjumlahan dalam kehidupan sehari-hari.

Mengenai materi matematika yang merupkan salaha satu materi yang sangat penting untuk di pelajari agar siswa dapat melakukan operasi hitung pada bilangan dengan baik dan dapat diterapkan dalam kehidupan sehari-hari. Dalam penelitian (Ningrum and Leonard, 2015) yang berjudul pengembangan desain pembelajaran matematika sekolah dasar kelas 1 mengungkapkan bahwa bahwa fokus pembelajaran matematika Sekolah Dasar kelas 1 ini terdiri atas 6 bab, yaitu bilangan sampai 20, penjumlahan dan pengurangan sederhana, pengukuran panjang, tinggi, dan berat, bilangan sampai 99, penjumlahan dan pengurangan sampai 99, serta bangun datar sederhana. Semua materi ini dikemas dalam desain semenarik mungkin didukung dengan pemilihan gambar untuk memudahkan peserta didik memahami isi pelajaran sehingga kemampuan pemecahan masalah dapat terfasilitasi dengan baik. Selain latihan-latihan soal, didalam bahan ajar tersebut juga 
terdapat beberapa kegiatan-kegiatan atau yang langsung dipraktekkan oleh peserta didik agar mereka bisa langsung merasakan mencari pemecahan masalahnya sendiri. Dengan hal ini diharapkan kemampuan pemecahan masalah matematika mereka dapat berkembang dengan baik.

Pada penelitian yang dilakukan Elly (2017) terkait dengan materi matematika pada buku guru dan buku siswa di kelas IV, V, VI pada kurikulum 2013 ini ada 2 persepsi yaitu berdasarkan penelitian analisis data tentang persepsi guru terhadap materi matematika dapat dilihat bahwa (51,39\%) responden mengatakan materi matematika sudah baik dan sesuai dengan kurikulum 2013, serta materi yang ada mudah dipahami peserta didik. Sedangkan terdapat $(48,61 \%)$ responden mengatakan bahwa ada beberapa materi yang ada di buku guru dan buku siswa masih belum lengkap dan sulit dipahami oleh peserta didik. Dari hasil penelitianyang dilakukan disimpulkan bahwa persepsi guru terhadap materi matematika yang ada pada guru dan buku siswa belum sepenuhnya baik.

Sejalan dengan hal tersebut, bedasarkan penelitian yang dilakukan oleh (Sulistyani \& Deviana, 2019) menunjukkan bahwa semua KD dalam mata pelajaran matematika mengharuskan peserta didik dapat mencapai kemampuan berpikir tingkat tinggi atau HOTS (Higher Order Thinking Skills). Dan secara umum bahan ajar matematika untuk kelas V SD masih berfikir dari umum ke khusus. Sehingga belum mampu mengkonstruksi pengetahuan siswa sampai tahap penemuan konsep. Perlu adanya bahan ajar yang memuat langkah-langkah kegiatan yang mampu mengakomodasi peserta didik menemukan konsep melalui pembelajaran bermakna.

Berdasarkan beberapa penelitian terdahulu dari beberapa tingkatan jenjang di sekolah dasar dapat diambil kesimpulan bahwa materi matematika yang ada dalam buku tematik masih perlu perbaikan. Begitu pula dengan penelitian yang dilakukan penulis berdasarkan temuan pada penelitian analisis muatan matematika pada buku tematik kurikulim 2013 ini masih perlu adanya perbaikan. Perbaikan tersebut dilakukan agar tujuan pembelajaran matematika ini dapat tercapai sesuai dengna yang diharapkan. Sehingga peserta didik memiliki kompetensi yang baik terutama dalam bidang matematika.

\section{Simpulan}

Penelitian ini menghasilkan temuan bahwa muatan matematika dalam buku tematik kelas $1 \mathrm{SD} / \mathrm{MI}$ materi matematika hanya terdapat pada pembelajaran 3, 5, dan 6. Materi matematika dalam buku tematik pada tema 1 Diriku, 
terutama pada materi bilangan masih perlu perbaikan. Karena antara KD dengan materi pembelajaran kurang sesuai. Mengenai kesesuaian materi dengan soal dalam buku tematik ini sudah sesuai. Akan tetapi, soal-soal yang ada perlu diperbanyak lagi. Oleh karena itu, pada penelitian lanjutan di perlukannya perbaikan pada buku tematik agar tujuan pembelajaran dapat tercapai sesuai dengan yang diharapkan.

\section{Daftar Pustaka}

Elly, Rosma. 2017. Persepsi Guru Terhadap Materi Matematika Di Buku Guru dan Buku Siswa Kelas IV, V, VI Pada Kurikulum 2013 Di Gugus Delima Kota Banda Aceh. Jurnal Ilmiah Pendididikan Guru Sekolah Dasar 2(8).

Hasanah, Sri Indriati, Ainur Rofiq Hafsi, \& Moh Zayyadi. 2019. Pengembangan Lembar Kerja Siswa Berbasis Etnomatematika Dalam Membangun Pemahaman Konsep Siswa. Jurnal Pendidikan Matematika dan IPA 10(2), 21.

Kurniawan, Ikhsan, Toufan Diansyah Tambunan, \& Indra Lukmana Sardi. N.D. 2015. Game Pembelajaran Matematika Untuk Anak SD Kelas 1 Dan 2 Berbasis Android Menggunakan Construct 2. 7(1).

Ningrum, Dwi Setia, \& Leonard Leonard. 2015. Pengembangan Desain Pembelajaran Matematika Sekolah Dasar Kelas 1. Formatif: Jurnal Ilmiah Pendidikan Mipa 4(3).

Prastowo, Andi. 2013. Pengembangan Bahan Ajar Tematik. Yogyakarta: Diva Press.

Putra, Nusa. 2012. Metode Penelitian Kualitatif Pendidikan. Jakarta: PT. Raja Grafindo Persada.

Rukiah, N.D. 2018. Meningkatkan Kemampuan Operasi Hitung Siswa Pada Pembelajaran Matematika Dengan Menggunakan Permainan Kartu Di Kelas II SDN Habau Tahun Pelajaran 2016/2017 12(1).

Sugiono. 2013. Metode Penelitian Pendidikan Pendekatan Kualitatif, Kuantitadif, dan R\&D. Bandung: Alfabeta.

Sulistyani, Nawang, \& Tyas Deviana. N.D. 2019. Analisis Bahan Ajar Matematika Kelas V SD Di Kota Malang, 9(1).

Wahyuni, Hermin Tri, Punaji Setyosari, \& Dedi Kuswandi. N.D. 2016. Implementasi Pembelajaran Tematik Kelas 1 SD 8(1). 